\title{
Correlation between mammalian cell cytotoxicity of flavonoids and the redox potential of phenoxyl radical/phenol couple
}

\author{
Audronè Marozienè ${ }^{1}$, Aušra Nemeikaitè-Čènienè ${ }^{1,2}$, Regina Vidžiūnaitè ${ }^{1}$ \\ and Narimantas Čènas ${ }^{\circledR}$ \\ IInstitute of Biochemistry of Vilnius University, Vilnius, Lithuania; ${ }^{2}$ Center of Innovative Medicine, Vilnius, Lithuania
}

\begin{abstract}
Flavonoids exhibit prooxidant cytotoxicity in mammalian cells due to the formation of free radicals and oxidation products possessing quinone or quinomethide structure. However, it is unclear how the cytotoxicity of flavonoids depends on the ease of their single-electron oxidation in aqueous medium, i.e., the redox potential of the phenoxyl radical/phenol couple. We verified the previously calculated redox potentials for several flavonoids according to their rates of reduction of cytochrome $c$ and ferricyanide, and proposed experimentally-based values of redox potentials for myricetin, fisetin, morin, kaempferol, galangin, and naringenin. We found that the cytotoxicity of flavonoids $(n=10)$ in bovine leukemia virus-transformed lamb kidney fibroblasts (line FLK) and murine hepatoma (line MH-22a) increases with a decrease in their redox potential of the phenoxyl radical/phenol couple and an increase in their lipophilicity. Their cytotoxicity was decreased by antioxidants and inhibitors of cytochromes P-450, a-naphthoflavone and isoniazide, and increased by an inhibitor of catechol-O-methyltransferase, 3,5-dinitrocatechol. It shows that although the prooxidant action of flavonoids may be the main factor in their cytotoxicity, the hydroxylation and oxidative demethylation by cytochromes P-450 and O-methylation by catechol-Omethyltransferase can significantly modulate the cytotoxicity of the parent compounds.
\end{abstract}

Key words: flavonoids, antioxidants, oxidative stress, cytotoxicity Received: 23 December, 2011; revised: 11 May, 2012; accepted: 01 June, 20912; available on-line: 13 June, 2012

\section{INTRODUCTION}

Flavonoids are universally recognized antioxidants which can protect the cell from the oxidative stress, i.e., neutralise the damaging effect of reactive oxygen species (ROS). However, at high concentrations, flavonoids and other polyphenols may be cytotoxic, causing an increase in mitochondrial permeability, cytochrome $c$ release, the activation of caspases, an increase in levels of p53 and $\mathrm{p} 21$, the suppression of $\mathrm{Bcl}-2$, apoptosis induction, and necrotic cell death (Bolton et al., 2000; Inayat-Hussain et al., 2001; Morin et al., 2001; Salvi et al., 2002; Shen et al., 2004; Lee et al., 2011).

There are several mechanisms of the cytotoxicity of flavonoids, including the inhibition of topoisomerases (Webb \& Ebeler, 2004; Bandele et al., 2008) and kinases (Gamet-Payrastre et al., 1999; Hou \& Kumamoto, 2010), and their prooxidant action (Mioshi et al., 2007; Sharma et al., 2007, and references therein). The prooxidant action is evidenced by an increase in ROS levels and lipid peroxidation under the action of flavonoids and other polyphenols, which is prevented by antioxidants and transition metal-chelating agents (Sergedienè et al., 1999; Galati et al., 2002; Nemeikaite-Čenienè et al., 2005). The prooxidant cytotoxicity may arise due to the formation of quinone- or quinomethide-type oxidation products of polyphenols that arylate reduced glutathione (GSH) and other cellular nucleophiles (Metodiewa et al., 1999; Boersma et al., 2000; Awad et al., 2002; Lu et al., 2006). The single-electron oxidation of polyphenols to phenoxyl radicals may lead to the cooxidation of NAD(P)H and other cellular reductants with the concomitant ROS formation (Galati et al., 1999,2002). In the cell, flavonoids and other polyphenols can be oxidized by the transition metals, mitochondrial $b c_{1}$ complex and cytochrome $c$ (Rich \& Bendall, 1980; Rich, 1982; Yoshino \& Murakami, 1998; Moini et al., 1999), and during the reductive $\mathrm{Fe}^{2+}$ mobilization from ferritin (Hynes \& Coinceanainn, 2002). Flavonoids also autooxidize in cell growth medium with the production of extracellular $\mathrm{H}_{2} \mathrm{O}_{2}$ (Nemeikaitè-Čenienè et al., 2005; Robaszkiewicz et al., 2007).

The structural factors determining the prooxidant cytotoxicity of flavonoids are not well understood. One may expect that the cytotoxicity of flavonoids, if determined by their prooxidant action, may increase with a decrease in the redox potential of the semiquinone/ hydroquinone (or phenoxyl radical/phenol) couple $\left(E_{7}\right.$ $\left.\left(\mathrm{Q}^{-}-/ \mathrm{QH}_{2}\right)\right)$. This relationship has been demonstrated for a related group of antioxidants, polyhydroxybenzenes (Nemeikaite-Cèniené et al., 2005; Grellier et al., 2008). It reflects the relative ease of formation of prooxidant oxidation products or ROS by hydroquinones and other polyphenols, because the rates of their oxidation by cytochromes, $\mathrm{Fe}^{3+}$, ferritin, or oxygen increase with a decrease in their $E_{7}\left(Q^{*}-/ \mathrm{QH}_{2}\right)$ (Rich \& Bendall, 1980; Rich, 1982; O’Brien, 1991; Hynes \& Coincemainn, 2002). However, the values of $E_{7}\left(Q^{*}-/ \mathrm{QH}_{2}\right)$ have been determined by pulse-radiolysis for a few flavonoids only, and for several other flavonoids redox potentials based

e-mail: narimantas.cenas@bchi.vu.It

Abbreviations: BCNU, 1,3-bis(2-chloroethyl)-1-nitrosourea; $\mathrm{CL}_{50}$, concentration of agent for $50 \%$ cell death; COMT, catechol-Omethyltransferase; DPPD, $N, N^{\prime}$-diphenyl-p-phenylene diamine; $E_{7}\left(\mathrm{Q}^{-} / \mathrm{QH}_{2}\right)$, redox potential of semiquinone/hydroquinone (phenoxyl radical/phenol) couple at $\mathrm{pH} 7.0 ; E_{7}\left(\mathrm{Q}^{-} / \mathrm{QH}_{2}\right)_{\text {(calc), calcu- }}$ lated redox potential of semiquinone/hydroquinone (phenoxyl radical/phenol) couple at $\mathrm{pH} 7.0 ; \mathrm{GSH}$, reduced glutathione; $k_{\mathrm{app}}$, apparent first order rate constant; $k$, second order rate constant; $P$, octanol/water partition coefficient; QSAR, quantitative structureactivity relationship; ROS, reactive oxygen species 


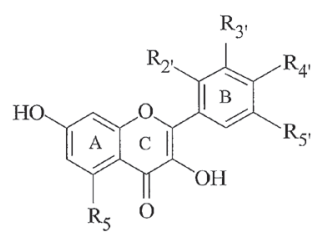

Flavonols

$\mathrm{R}_{5}=\mathrm{R}_{3^{\prime}}=\mathrm{R}_{4^{\prime}}=\mathrm{R}_{5^{\prime}}=\mathrm{OH} ; \mathrm{R}_{2^{\prime}}=\mathrm{H} \quad$ Myricetin

$\mathrm{R}_{5}=\mathrm{R}_{3^{\prime}}=\mathrm{R}_{4^{\prime}}=\mathrm{OH} ; \mathrm{R}_{2^{\prime}}=\mathrm{R}_{5^{\prime}}=\mathrm{H}$ Quercetin

$\mathrm{R}_{5}=\mathrm{R}_{2^{\prime}}=\mathrm{R}_{4^{\prime}}=\mathrm{OH} ; \mathrm{R}_{3^{\prime}}=\mathrm{R}_{5^{\prime}}=\mathrm{H} \quad$ Morin

$\mathrm{R}_{5}=\mathrm{R}_{4^{\prime}}=\mathrm{OH} ; \mathrm{R}_{2^{\prime}}=\mathrm{R}_{3^{\prime}}=\mathrm{R}_{5^{\prime}}=\mathrm{H} \quad$ Kaempferol

$\mathrm{R}_{5}=\mathrm{OH} ; \mathrm{R}_{2^{\prime}}=\mathrm{R}_{3^{\prime}}=\mathrm{R}_{4^{\prime}}=\mathrm{R}_{5^{\prime}}=\mathrm{H}$ Galangin

$\mathrm{R}_{5}=\mathrm{R}_{2^{\prime}}=\mathrm{R}_{5^{\prime}}=\mathrm{H} ; \mathrm{R}_{3^{\prime}}=\mathrm{R}_{4^{\prime}}=\mathrm{OH}$ Fisetin<smiles>[R15]c1ccc(C2Oc3cc(O)cc(O)c3C(=O)C2[R3])cc1[R15]</smiles>

Flavanones

$\begin{array}{ll}\mathrm{R}_{3}=\mathrm{R}_{3^{\prime}}=\mathrm{R}_{4^{\prime}}=\mathrm{OH} & \text { Taxifolin } \\ \mathrm{R}_{3}=\mathrm{R}_{3^{\prime}}=\mathrm{H} ; \mathrm{R}_{4^{\prime}}=\mathrm{OH} & \text { Naringenin } \\ \mathrm{R}_{3}=\mathrm{H} ; \mathrm{R}_{3^{\prime}}=\mathrm{OH} ; \mathrm{R}_{4^{\prime}}=\mathrm{OCH}_{3} & \text { Hesperetin }\end{array}$<smiles>Oc1cc(O)c2c(c1)O[C@H](c1ccc(O)c(O)c1)C(O)C2</smiles>

Figure 1. Structural formulae of flavonoids studied.

on calculations are available (Jovanovic et al., 1998, and references cited therein). This hampers further studies in this direction.

In this study, we examined the reactivity of a series of flavonoids (Fig. 1) and model hydroxybenzenes possessing a broad range of $E_{7}\left(Q^{*}-/ \mathrm{QH}_{2}\right)$ values towards the single-electron oxidants cytochrome $c$ and ferricyanide. The obtained dependences enabled us to propose experimentally-based $E_{7}\left(Q^{*}-/ \mathrm{QH}_{2}\right)$ values for several flavonoids. Further, we demonstrated an increase in the mammalian cell cytotoxicity of flavonoids upon a decrease in their potential of the phenoxyl radical/phenol redox couple.

\section{MATERIALS AND METHODS}

Chemicals. Flavonoids (Fig. 1), cytochrome c, other enzymes and chemicals were obtained from Sigma-Aldrich and used as received.

Kinetic studies. The kinetic experiments were carried out spectrophotometrically in $0.1 \mathrm{M} \mathrm{K}$-phosphate buffer (pH 7.0), containing $1 \mathrm{mM}$ EDTA, at $25^{\circ} \mathrm{C}$. The reduction of cytochrome $c$ by myricetin, fisetin, and morin was monitored using a DX.17MV stopped-flow spectrophotometer (Applied Photophysic) assuming $\Delta \varepsilon_{550}=20 \mathrm{mM}^{-}$ ${ }^{1} \mathrm{~cm}^{-1}$. The concentrations of flavonoids and cytochrome $c$ after mixing were equal to $20-100 \mu \mathrm{M}$ and $4.0 \mu \mathrm{M}$, respectively. The apparent first order rate constants $\left(k_{\text {app }}\right)$ were obtained from the analysis of the kinetics of the absorbance increase according to a single-exponent fit, using the software supplied by Applied Photophysics. The second order rate constants $(k)$ were calculated from the slopes of the linear dependences of $k_{\text {app }}$ on the reductant concentration. Several experiments were performed with $500 \mu \mathrm{M}$ cytochrome $c$, and $20 \mu \mathrm{M}$ of each flavonoid, using a $0.2-\mathrm{cm}$ optical path cell. For other compounds, the bimolecular reaction rate constants were calculated from the initial rates of reduction of the excess cytochrome $c$ $(500-150 \mu \mathrm{M})$ by $20 \mu \mathrm{M}$ polyphenol, using a Hitachi-557 spectrophotometer and a $0.2-\mathrm{cm}$ optical path cell. When the initial reaction rates were measured, corrections were introduced in several cases for the absorbance of polyphenol oxidation products at $550 \mathrm{~nm}: \Delta \varepsilon_{550}=0.8 \mathrm{mM}^{-1}$ $\mathrm{cm}^{-1}$ (catechin), $\Delta \varepsilon_{550}=0.28 \mathrm{mM}^{-1} \mathrm{~cm}^{-1}$ (taxifolin, caffeic acid), and $\Delta \varepsilon_{550}=0.2 \mathrm{mM}^{-1} \mathrm{~cm}^{-1}$ (ethylgallate, catechol). The absorbance of the oxidation products at $550 \mathrm{~nm}$ was determined after the oxidation of the polyphenols by excess ferricyanide.

The reduction of ferricyanide by flavonoids and hydroxybenzenes was monitored at $420 \mathrm{~nm}$ using excess ferricyanide (final concentrations, $0.4-1.8 \mathrm{mM}$ ) over the reductant (final concentrations, $0.05-0.2 \mathrm{mM}$ ). Additional measurements were performed by monitoring the kinetics of the decrease of the absorbance of the reductant at $370 \mathrm{~nm}$ (myricetin, quercetin, morin), $365 \mathrm{~nm}$ (kaempferol, fisetin), and $320 \mathrm{~nm}$ (hesperetin). The reaction rate constants above $10 \mathrm{M}^{-1} \mathrm{~s}^{-1}$ were determined using a stopped-flow spectrophotometer. Because the oxidation of polyphenols is sometimes accompanied by the slower formation of secondary products (Terland et al., 2006), only the initial stage of the processes was analyzed according to a single-exponent fit. For the slowly reacting compounds, the reaction rates were measured using a Hitachi-557 spectrophotometer. In those cases, the $k_{\text {app }}$ values were determined according to the Guggenheim method from the plots $\ln \Delta \mathrm{A} v$ s. $\mathrm{t}$, where $\Delta \mathrm{A}$ is the absorbance changes at equal time intervals (Connors, 1990). The second order rate constants were calculated from the plots $k_{\text {app }} v s$. ferricyanide concentration.

Cell culture cytotoxicity studies. Cultures of bovine leukemia virus-transformed lamb kidney fibroblasts (line FLK) and murine hepatoma (line MH-22) were grown and maintained at $37^{\circ} \mathrm{C}$ in Eagle's medium or in DMEM medium, respectively, supplemented with $10 \%$ fetal bovine serum and antibiotics, as described (Nemeikaitè-Čènienè et al., 2005; Grellier et al., 2008). In the cytotoxicity experiments, cells $\left(2.5 \times 10^{4} / \mathrm{ml} \mathrm{FLK}\right.$, and $3.0 \times 10^{4} / \mathrm{ml} \mathrm{MH-22a)}$ were seeded on $18 \times 18 \mathrm{~mm}$ glass slides in $5-\mathrm{ml}$ flasks either in the presence or in the absence of compounds, and were grown for $24 \mathrm{~h}$. Then, the slides were rinsed 3-4 times with phosphate buffered saline and stained with Trypan blue. The cells adherrent to the slides were counted under a light microscope. Typically, they did not accumulate Trypan blue and their viability was $98.5-99.3 \%$. Stock solutions of poorly soluble compounds were prepared in dimethyl sulfoxide. Its concentration in cultivation media did not exceed $0.2 \%$, and did not affect cell viability. The experiments were conducted in triplicate.

Log $\mathbf{P}$ calculation, statistical analysis. The octanol/ water partition coefficients of flavonoids $(\log P)$ were calculated using the ACD/ChemSketch software (version 4.02, Advanced Chemistry Development, Toronto, Ontario, Canada), while statistical and multiparameter regression analysis was performed using Statistica (version 4.3, Statsoft Inc., 1993).

\section{RESULTS}

\section{Kinetics of reduction of cytochrome $c$ and ferricyanide by flavonoids and hydroxybenzenes}

Among the flavonoids examined (Fig. 1), the redox potentials for quercetin, taxifolin, catechin, and hesperetin were obtained directly from pulse-radiolysis studies, whereas the values of $E_{7}\left(\mathrm{Q}^{*}-\mathrm{QH}_{2}\right)$ for other flavonoids (Table 1) are based on calculations (Jovanovic et al., 1998). In order to verify the calculated $E_{7}\left(Q^{*}-/ \mathrm{QH}_{2}\right)$ values, we examined the reactions of the flavonoids and a number of model polyhydroxybenzenes with the $E_{7}\left(Q^{-}-/ \mathrm{QH}_{2}\right)$ values from $0.33 \mathrm{~V}$ to $0.73 \mathrm{~V}$ (Table 1$)$, 
Table 1. Kinetic and thermodynamic characteristics of flavonoids and hydroxybenzenes.

Redox potentials of phenoxyl radical/phenol couples of flavonoids and hydroxybenzenes at $\mathrm{pH} 7.0\left(E_{7}\left(\mathrm{Q}^{-}-/ \mathrm{QH}_{2}\right)\right)(\mathrm{Wardman}, 1989 ;$ Jovanovic et al., 1998; Lin et al., 1998), their bimolecular rate constants of reduction of cytochrome $c$ and ferricyanide ( $k$ ), and their redox potentials of phenoxyl radical/phenol couples calculated according to Eqn. (1) $\left(E_{7}\left(\mathrm{Q}^{*} / \mathrm{QH}_{2}\right)_{(\mathrm{calc})}\right)$, standard error of estimate, $\left.\pm 0.04 \mathrm{~V}\right)$.

\begin{tabular}{|c|c|c|c|c|}
\hline Compound & $E_{7}\left(\mathrm{Q}-/ \mathrm{QH}_{2}\right)(\mathrm{V})^{\mathrm{a}}$ & & $\left.s^{-1}\right)$ & $E_{7}\left(\mathrm{Q} \cdot-/ \mathrm{QH}_{2}\right)_{7 \text { (calc.) }}(\mathrm{V})$ \\
\hline & & cytochrome $c$ & ferricyanide ${ }^{c}$ & \\
\hline Quercetin & 0.33 & $390 \pm 20^{b}$ & $1460 \pm 150$ & 0.36 \\
\hline Fisetin & $(0.33)$ & $220 \pm 30$ & $2200 \pm 200$ & 0.36 \\
\hline Myricetin & $(0.36)$ & $1030 \pm 50 ; 970 \pm 60^{b}$ & $7500 \pm 700$ & 0.31 \\
\hline$t$-Butylhydroquinone & 0.46 & $5.9 \pm 0.3 ; 5.6 \pm 0.5^{b}$ & $117 \pm 17.0$ & 0.50 \\
\hline Hydroquinone & 0.48 & $11.6 \pm 0.9^{b}$ & $170 \pm 5.0$ & 0.48 \\
\hline Taxifolin & 0.50 & $1.0 \pm 0.1^{b}$ & $32.0 \pm 3.0$ & 0.56 \\
\hline Catechol & 0.53 & $2.1 \pm 0.2$ & $65.5 \pm 5.0$ & 0.54 \\
\hline Ethylgallate & 0.56 & $7.3 \pm 0.5^{b}$ & $200 \pm 20$ & 0.49 \\
\hline Catechin & 0.57 & $2.0 \pm 0.5$ & $35.6 \pm 2.0$ & 0.55 \\
\hline Morin & $(0.60)$ & $90.5 \pm 5.0 ; 98.0 \pm 8.0^{b}$ & $800 \pm 50$ & 0.40 \\
\hline 3,4-Dioxybenzoic acid & 0.60 & $3.3 \pm 0.2$ & $7.1 \pm 0.6$ & 0.57 \\
\hline Galangin & $(0.62)$ & $0.03 \pm 0.004$ & $0.69 \pm 0.15$ & 0.72 \\
\hline Ferrulic acid & 0.69 & $0.04 \pm 0.003$ & $10.0 \pm 0.7$ & 0.66 \\
\hline Hesperetin & 0.72 & $0.01 \pm 0.002$ & $0.5 \pm 0.04$ & 0.75 \\
\hline p-Methoxyphenol & 0.73 & $0.005 \pm 0.001$ & $1.8 \pm 0.15$ & 0.73 \\
\hline Kaempherol & $(0.75)$ & $92.0 \pm 7.0^{\mathrm{b}}$ & $1400 \pm 100$ & 0.39 \\
\hline Naringenin & - & $\leq 0.002$ & $0.3 \pm 0.03$ & 0.79 \\
\hline
\end{tabular}

aThe calculated $E^{2}$, values for flavonoids (Jovanovic et al., 1998) are shown in parentheses. bFrom Nemeikaitè-Čènienè et al., 2005. cDetermined from the absorbance changes at $420 \mathrm{~nm}$.

with two single-electron oxidants, cytochrome $c$ and ferricyanide. According to the model of an ,outer-sphere electron-transfer, one may expect a linear dependence of $\log$ (rate constant) on the difference between the redox potential of a single-electron oxidant and a series of homologous reductants, e.g., polyphenols, if the reactions are endothermic or modestly exothermic (Marcus \& Su-

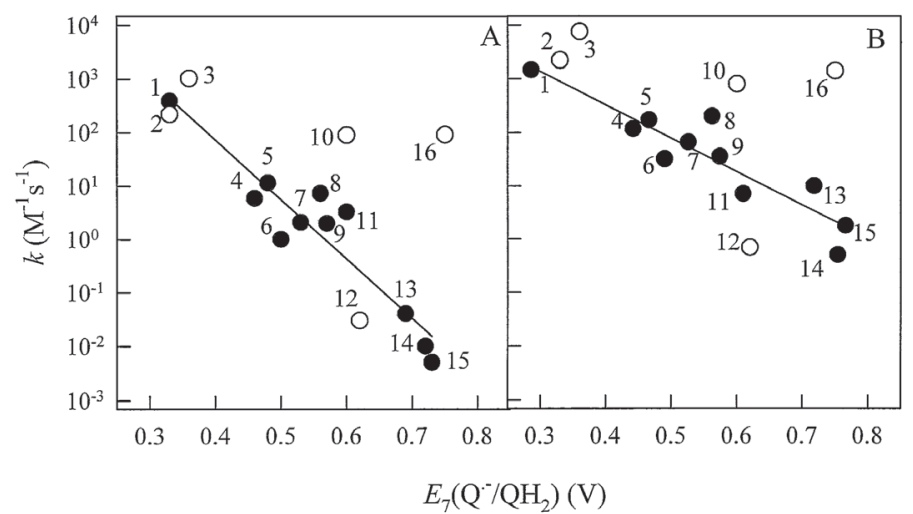

Figure 2. The dependence of reduction rate constants of cytochrome $c$ (A) and ferricyanide (B) on the redox potentials of phenoxyl radical/phenol couple of polyphenols.

First order regression lines are drawn through the values of bimolecular reaction rate constants $(k)$ of polyphenols with experimentally determined $E_{7}\left(\mathrm{Q}^{-}-1\right.$ $\mathrm{QH}_{2}$ ) values (solid circles). The reactivity of flavonoids with the calculated values of $E_{7}\left(\mathrm{Q}^{--} / \mathrm{OH}_{2}\right)$ (blank circles) is shown for comparison. Numbering of compounds, their $k$ and $E_{7}\left(\mathrm{Q}-\mathrm{QH}_{2}\right)$ values are taken from Table 1: quercetin (1), fisetin (2), myricetin (3), $t$-butylhydroquinone (4), hydroquinone (5), taxifolin (6), catechol (7), ethylgallate (8), catechin (9), morin (10), 3,4-dioxybenzoic acid (11), galangin (12), ferrulic acid (13), hesperetin (14), p-methoxyphenol (15), kaempferol (16), and naringenin (17). tin, 1985). A similar approach, based on linear log (rate constant) vs. redox potential dependences was used in the determination of unknown values of single-electron reduction potentials for nitroaromatic compounds (Čènas et al., 2009; Uchimiya et al., 2010, and references therein).

The bimolecular rate constants $(k)$ of the reduction of cytochrome $c$ by hydroxybenzenes and flavonoids, determined in the present study or taken from our previous work (Nemeikaitè-Čènienè et al., 2005), are given in Table 1. In stoppedflow experiments, the reactions followed the first order kinetics. The rate constants determined using either excess polyphenol over cytochrome $c$ or excess cytochrome $c$ over polyphenol were identical within an experimental error. Supporting the previous observations (Nemeikaité-Čenienè et al., 2005), the reactivity of hydroxybenzenes and flavonoids increased with a decrease in their experimentally determined $E_{7}\left(\mathrm{Q}^{*}-\mathrm{QH}_{2}\right)$ values, with $\Delta \log \quad k / \Delta E_{7}\left(Q^{*}-/ \mathrm{QH}_{2}\right)=-11.15 \pm 1.40 \quad \mathrm{~V}^{-1}$ $\left(r^{2}=0.876, \mathrm{~F}(1,9)=63.42\right)$ (Fig. 2A). One may note that the reactivities of fisetin and myricetin were close to those expected from their calculated $E_{7}\left(Q^{*}-/ \mathrm{QH}_{2}\right)$ values, whereas the reactivity of galangin was lower, and those of morin and kaempferol were much higher than expected (Fig. 2A).

The reduction of ferricyanide by all the polyphenols examined except hydroquinone and $t$-butylhydroquinone was accompanied by the formation of oxidation products absorbing at $420 \mathrm{~nm}$ and above. It diminished the expected amplitude of absorbance 


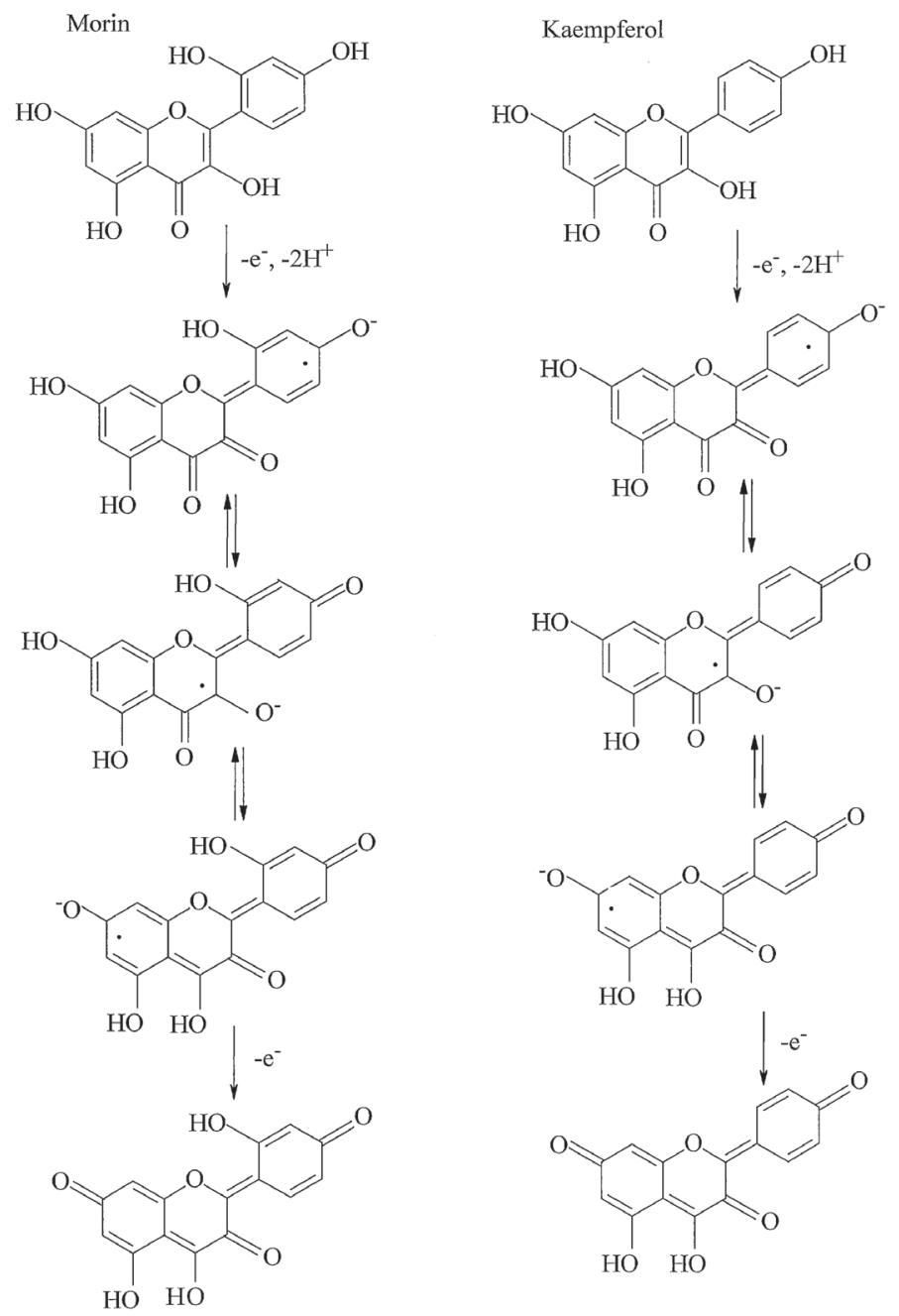

$E_{7}\left(Q^{-}-/ \mathrm{QH}_{2}\right)$ values for morin and kaempferol (Jovanovic et al., 1998).

\section{Calculation of $E_{7}\left(Q \cdot / Q \mathrm{Q}_{2}\right)$ for flavonoids according to the kinetic data}

For the calculation of unavailable values of $E_{7}\left(Q^{*}-/ \mathrm{QH}_{2}\right)$ for flavonoids we used the geometric average of cytochrome $c$ and ferricyanide reduction rate constants (Table 1) as a correlation parameter:

$\log k=(6.00 \pm 1.07)-(9.30 \pm 1.07) E_{7}\left(\mathrm{Q}^{-} / \mathrm{QH}_{2}\right)$ $\left(r^{2}=0.893, \mathrm{~F}(1,9)=75.42\right)$.

The $E_{7}\left(\mathrm{Q}^{-}-/ \mathrm{QH}_{2}\right)$ values calculated according to Eqn. (1) $\left(E_{7}\left(\mathrm{Q}^{-}-/ \mathrm{QH}_{2}\right)_{\text {(calc.) }}\right.$, Table 1) are sufficiently close to the experimentally determined redox potentials, with an average difference of $\pm 40 \mathrm{mV}$. In comparison, the experimental error in the determination of redox potential by pulse-radiolysis is $\pm 10-15 \mathrm{mV}$ (Jovanovic et al., 1998; Wardman, 1989).

Concerning the obtained $E_{7}\left(Q^{*}-/ \mathrm{QH}_{2}\right)_{\text {(calc.) }}$ values for flavonoids, the calculated redox potentals for naringenin and galangin (Table 1) are close to that of resorcinol, $0.81 \mathrm{~V}$, which reflects the ease of oxidation of the resorcinol group in the A-ring of flavonoids Jovanovic et al., 1998). The $E_{7}\left(Q^{*}-/ \mathrm{QH}_{2}\right)_{\text {(calc.) }}$ for myricetin and fisetin (Table 1) are close to their previously calculated values (Jovanovic et al., $1998)$. In contrast, the $E_{7}\left(Q^{*}-/ \mathrm{QH}_{2}\right)_{\text {(calc.) }}$ values for morin and kaempferol (Table 1) are much more negative than those suggested previously (Jovanovic et al., 1998). In our opinion, the previous calculations (Jovanovic et al., 1998) could have underestimated the effects of charge delocalization in flavonol anionradicals, which may result in their stabilization and a decrease in their $E_{7}\left(Q^{-}-/ \mathrm{QH}_{2}\right)$ values (Scheme 1). The quinone/quinomethide tautomerisation of flavonoid oxidation products was experimentally demonstrated in quercetin decrease at $420 \mathrm{~nm}$. However, the absorbance changes at $420 \mathrm{~nm}$ during ferricyanide reduction by myricetin, quercetin, morin, kaempferol, fisetin, and ethylgallate followed the first order kinetics for more than 6-8 reaction half-times. In this time scale, the kinetics of oxidation of myricetin, quercetin, morin, kaempferol, and fisetin monitored at their $\lambda_{\max }, 365-370 \mathrm{~nm}$, followed the first order as well. Their $k_{\text {app }}$ values were identical within the experimental error to those obtained at $420 \mathrm{~nm}$. On the other hand, the biphasic absorbance changes at $420 \mathrm{~nm}$ during the reduction of ferricyanide by taxifolin, catechin, and catechol were more pronounced (not shown). In those cases, only the initial stages of the process, 3-4 reaction half-times, were analyzed according to a single-exponent fit. The oxidation of other slowly reacting polyphenols also followed the first order kinetics. The data of Table 1 show that the reactivity of hydroxybenzenes and flavonoids towards ferricyanide increased with a decrease in their experimentally determined $E_{7}\left(\mathrm{Q}^{*}-/ \mathrm{QH}_{2}\right)$ values with $\Delta \log k / \Delta E_{7}\left(Q^{\cdot-} / Q_{2}\right)=-7.47 \pm 1.11 \mathrm{~V}^{-1} \quad\left(r^{2}=0.835\right.$, $\mathrm{F}(1,9)=45.41$ ) (Fig. 2B). Again, like in the reduction of cytochrome $c$ (Fig. 2A), the reactivities of morin and kaempferol were much higher than expected (Fig. 2B). It shows that these deviations are not caused by the specificity of the particular flavonoids towards cytochrome $c$, but most probably by the overestimation of calculated oxidation (Boersma et al., 2000; Awad et al., 2002). This way of stabilization is not characteristic for other groups

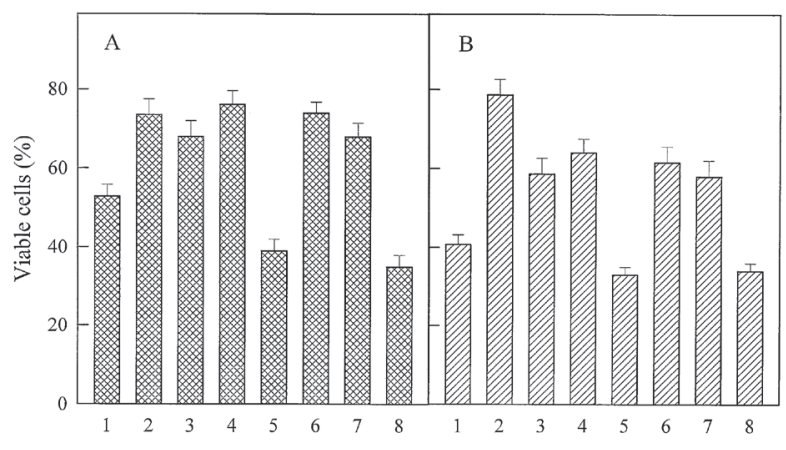

Figure 3. Toxicity of myricetin and galangin in $\mathrm{MH}-22 \mathrm{a}$ cells, and the effects of antioxidants, prooxidants, and cytochrome P-450 and COMT inhibitors.

Concentration of myricetin, $60 \mu \mathrm{M}(\mathrm{A})$, concentration of galangin, $300 \mu \mathrm{M}(\mathrm{B})$, additions: none (1), $2.5 \mu \mathrm{M}$ DPPD (2), $300 \mu \mathrm{M}$ desferrioxamine (3), $100 \mathrm{U} / \mathrm{ml}$ catalase (4), $20 \mu \mathrm{M}$ BCNU (5), $5.0 \mu \mathrm{M}$ a-naphthoflavone (6), $1.0 \mathrm{mM}$ isoniazide (7), and $5.0 \mu \mathrm{M} 3,5$-dinitrocatechol (8). $n=3, P<0.02$ for $2-4,6,7$ against 1 , and $P<0.05$ for 5,8 against 1. 


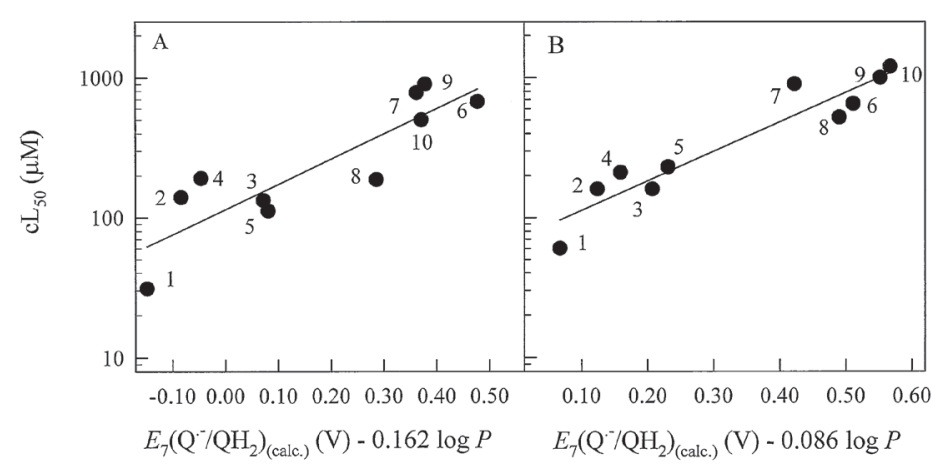

Figure 4. QSARs in flavonoid cytotoxicity in FLK (A) and MH-22a (B) cells. Dependence of flavonoid cytotoxicity on their calculated redox potential of phenoxyl radical/phenol couple, $E_{7}\left(\mathrm{Q}^{-}-\mathrm{QH}_{2}\right)_{\text {(calc }}$ and octanol/water partition coefficient, $\log P$, according to multiparameter Eqs. $(2,3)$. Numbering of compounds and their $E_{7}\left(\mathrm{Q}^{-} / \mathrm{QH}_{2}\right)_{\text {(calc.) }}$ values are taken from Table 2: myricetin (1), quercetin (2), fisetin (3), kaempferol (4), morin (5), catechin (6), taxifolin (7), galangin (8), hesperetin (9), and naringenin (10).

of flavonoids. The obtained low $E_{7}\left(\mathrm{Q}^{\bullet}-\mathrm{QH}_{2}\right)$ values for morin and kaempferol are in line with their voltammetric characteristics. Although morin and kaempferol do not possess an electrochemically reversible catechol group in B-ring, their electrochemical oxidation is reversible, with the voltammetric midpoint potentials at $\mathrm{pH} 7.4$ being equal to $0.34 \mathrm{~V}$ and $0.39 \mathrm{~V}$, respectively, which is close to the midpoint potential of quercetin, $0.29 \mathrm{~V}$ (Jorgensen \& Skibstedt, 1998). This may be explained by the formation of quinomethides as two-electron oxidation products (Scheme 1). In contrast, an analogue of kaempferol, the flavone apigenin, which lacks 3-OH group in C-ring, is oxidized irreversibly with the peak potential at $0.71 \mathrm{~V}$ (Jorgensen \& Skibstedt, 1998). Thus, the values of $E_{7}$ $\left(\mathrm{Q}^{-}-\mathrm{QH}_{2}\right)$ of flavonoids obtained in this work may be considered as reasonable approximations.

\section{Prooxidant mammalian cell cytotoxicity of flavonoids}

The prooxidant action of quercetin, myricetin, and several polyhydroxybenzenes in FLK and HL-60 cells has been confirmed before (Nemeikaitè-Čènienè et al., 2005). In this work we examined the action of myricetin and galangin in $\mathrm{MH}-22 \mathrm{a}$ cells. The latter compound is of considerable interest because it does not possess $\mathrm{OH}$ - groups in B-ring (Fig. 1). The cytotoxicity of both compounds was partly decreased by the antioxidant $N, N^{\prime}$-diphenyl-p-phenylene diamine (DPPD) and the iron-chelating agent desferrioxamine, and potentiated by the prooxidant 1,3-bis(2-chloroethyl)-1-nitrosourea $(\mathrm{BCNU})$, which inactivates the antioxidant enzyme glutathione reductase and depletes intracellular GSH (Öllinger \&Brunmark, 1991) (Fig. 3A, B). The protective effect of exogenous catalase (Fig. 3A, B) shows that the formation of extracellular $\mathrm{H}_{2} \mathrm{O}_{2}$ contributes to their cytotoxicity, evidently due to their oxidation in cell growth media (Morita et al., 2003; Robaszkiewicz et al., 2007). The cytotoxicity was also partly decreased by the inhibitor of cytochromes P-450 1A1/ A2, $\alpha$-naphthoflavone, and the inhibitor of cytochrome P-450 2E1, isoniazide, and potentiated by an inhibitor of catechol-O-methyltransferase (COMT), 3,5-dinitrocatechol (Moridani et al., 2002a; 2002b) (Fig. 3A, B). It points to a common prooxidant cytotoxicity mechanism of both compounds.
Quantitative structure-activity relationships (QSARs) in the cytotoxicity of flavonoids

The concentrations of flavonoids causing $50 \%$ death of FLK and MH-22a cells $\left(\mathrm{cL}_{50}\right)$, determined in the present work or taken from our previous studies (Nemeikaitè-Čenienè et al., 2005; Grellier et al., 2008), and the previously obtained $\mathrm{cL}_{50}$ values of flavonoids in human promyelocytic leukemic cells (line HL60) Nemeikaitè-Cènienè et al., 2005; Grellier et al., 2008) are given in Table 2, together with their $E_{7}\left(\mathrm{Q}^{*}-/ \mathrm{QH}_{2}\right)_{\text {(calc.) }}$ values. Because the cytotoxicity of polyhydroxybenzenes increases with an increase in their lipophilicity (Nemeikaitè-Čeniene et al., 2005), the calculated octanol/water partition coefficients for flavonoids, $\log P$, are also given in Table 2 . The data analysis shows that the cytotoxicity of the flavonoids in general increases with a decrease in the energetics of their single-electron oxidation, but the dependence is relatively scatterred, with the coefficients $\Delta \log \mathrm{cL}_{50} /$ $\mathrm{E}_{7}\left(\mathrm{Q}^{\bullet}-\mathrm{QH}_{2}\right)_{\text {(calc.) }}$ equal to $1.86 \pm 0.62$ (FLK, $\left.r^{2}=0.527\right), 2.13 \pm 0.37$ (MH-22a, $\left.r^{2}=0.805\right)$, and $2.28 \pm 0.72$ (HL-60, $\left.r^{2}=0.665\right)$. There is no relationship between $\log$ $\mathrm{CL}_{50}$ and $\log P\left(r^{2}=0.275\right.$ (FLK), $r^{2}=0.138$ (MH-22a), and $r^{2}=0.343$ (HL-60)). On the other hand, a two-parameter analysis improved the regressions markedly, showing that the cytotoxicity of flavonoids increased with a decrease in their $E_{7}\left(\mathrm{Q}^{\cdot-} / \mathrm{QH}_{2}\right)_{\text {(calc.) }}$ and with an increase in $\log P$ :

$\log \mathrm{cL}_{50}=(2.06 \pm 0.35)+(1.80 \pm 0.46) E_{7}\left(\mathrm{Q}^{*} / \mathrm{QH}_{2}\right)_{\text {(calc.) }}$ $(0.29 \pm 0.11) \log P, r^{2}=0.769, \mathrm{~F}(2,7)=11.67$ (FLK),

$\log \mathrm{cL}_{50}=(1.84 \pm 0.20)+(2.10 \pm 0.26) E_{7}\left(\mathrm{Q}^{-}-\mathrm{QH}_{2}\right)_{\text {(calc.) }}$ $(0.18 \pm 0.06) \log P, r^{2}=0.916, \mathrm{~F}(2,7)=35.97(\mathrm{MH}-22 \mathrm{a})$,

and

$\log \mathrm{cL}_{50}=(2.22 \pm 0.62)+(2.01 \pm 0.59) \mathrm{E}_{7}\left(\mathrm{Q}^{\bullet}-/ \mathrm{QH}_{2}\right)_{\text {(calc.) }}-$ $(0.48 \pm 0.20) \log P, r^{2}=0.832, \mathrm{~F}(2,4)=9.88$ (HL-60).

The dependence of the cytotoxicity of flavonoids in FLK and $\mathrm{MH}-22 \mathrm{a}$ cells on their $E_{7}\left(\mathrm{Q}^{*}-/ \mathrm{QH}_{2}\right)_{\text {(calc.) }}$ and $\log P$ values is shown in Fig. 4A, B.

\section{DISCUSSION}

Although numerous studies on the prooxidant activity of flavonoids have been published (Mioshi et al., 2007; Sharma et al., 2007, and references therein), the relationship between their redox properties and the cytotoxicity has been addressed insufficiently so far. The available QSARs were based on the voltammetric oxidation potentials or on the calculated heats of formation of free radicals of flavonoids (Sergedienè et al., 1999; Moridani et al., 2003), which may not adequately reflect the energetics of single-electron oxidation of flavonoids in aqueous medium. In contrast, the values of $E_{7}\left(\mathrm{Q}^{-}-/ \mathrm{QH}_{2}\right)$ are directly related to an ,outer sphere“ electron-transfer model (Marcus \& Sutin, 1985), and well describe the reactivity of polyphenols towards single-electron oxidants (Rich \& Bendall, 1980; Rich, 1982). Thus, their use in QSARs may more adequately characterize the cytotoxicity mechanism(s) with respect to the possible prooxidant action of flavonoids. Our kinetic studies (Fig. 2A, B, Table 1) enabled us to extend the number of flavonoids with experimentally-based $E_{7}\left(\mathrm{Q}^{-}-/ \mathrm{QH}_{2}\right)$ values. Subsequently, we obtained QSARs for the first time, show- 
Table 2. Cytotoxic characteristics of flavonoids.

The values of redox potentials of phenoxyl radical/phenol couples of flavonoids at $\mathrm{pH} 7.0$ calculated according to Eqn. (1) $\left(E_{7}\left(\mathrm{Q}^{-} / \mathrm{QH}_{2}\right)_{(\mathrm{calc})}\right)$, the octanol/water partition coeficients of flavonoids (log $\left.P\right)$, and their concentrations for $50 \%$ survival $\left(\mathrm{CL}_{50}\right)$ of FLK, MH-22a, and HL-60 cells.

\begin{tabular}{llllll}
\hline Compound & $E_{7}\left(\mathrm{Q}^{-} / \mathrm{QH}_{2}\right)_{(\text {calc. })}$ & $\log P$ & & $\mathrm{CL}_{50}(\mu \mathrm{M}):$ & \\
\hline & $(\mathrm{V})$ & & $\mathrm{FLK}$ & $\mathrm{MK}-22 \mathrm{a}$ & $\mathrm{HL}-60$ \\
\hline Myricetin & 0.31 & 2.83 & $31.0 \pm 4.0 ; 34.0 \pm 5.0^{\mathrm{a}}$ & $60.0 \pm 3.0$ & $20 \pm 5.0^{\mathrm{a}}$ \\
Quercetin & 0.36 & 2.74 & $140 \pm 18^{\mathrm{a}}$ & $160 \pm 25^{\mathrm{b}}$ & $120 \pm 20^{\mathrm{a}}$ \\
Fisetin & 0.36 & 1.78 & $133 \pm 15$ & $160 \pm 20$ & - \\
Kaempferol & 0.39 & 2.69 & $192 \pm 30 ; 185 \pm 25^{\mathrm{a}}$ & $210 \pm 30$ & $125 \pm 20^{\mathrm{a}}$ \\
Morin & 0.40 & 1.97 & $112 \pm 15^{\mathrm{a}}$ & $230 \pm 25 ; 250 \pm 35^{\mathrm{b}}$ & $250 \pm 40^{\mathrm{a}}$ \\
Catechin & 0.55 & 0.45 & $676 \pm 30$ & $650 \pm 50$ & - \\
Taxifolin & 0.56 & 1.22 & $780 \pm 120^{\mathrm{a}}$ & $900 \pm 100^{\mathrm{b}}$ & $600 \pm 150^{\mathrm{a}}$ \\
Galangin & 0.72 & 2.68 & $188 \pm 20$ & $520 \pm 50$ & - \\
Hesperetin & 0.75 & 2.30 & $\geq 900 ; 750 \pm 100^{\mathrm{a}}$ & $1000 \pm 100$ & $500 \pm 100^{\mathrm{a}}$ \\
Naringenin & 0.79 & 2.59 & $500 \pm 60$ & $1200 \pm 100$ & $700 \pm 100^{\mathrm{b}}$ \\
\hline
\end{tabular}

aFrom Nemeikaitè-Čènienè et al., 2005. 'bFrom Grellier et al., 2008.

ing that the cytotoxicity of flavonoids in the three cell lines increases with a decrease in their $E_{7}\left(Q^{*}-/ \mathrm{QH}_{2}\right)_{\text {(calc.) }}$ values (Eqns. 2-4, Fig. 4A, B). Taken together with the protective effects of the antioxidants (Fig. 3A, B), this indicates that the oxidative stress may be a key factor for flavonoid cytotoxicity. An increase in the cytotoxicity of flavonoids with an increase in their lipophilicity (Eqsn. 2-4) points to the importance of their intracellular accumulation. The obtained QSARs and the effects of antioxidants, prooxidants, and inhibitors of cytochromes P-450 and COMT (Figs. 3,4) for flavonoids are similar to those observed in the action of polyhydroxybenzenes in the same cell lines (Nemeikaitè-Cenienè et al., 2005; Grellier et al., 2008). It shows that both groups of polyphenolic antioxidants may share the same main mechanism(s) of prooxidant cytotoxicity.

On the other hand, the dependence of flavonoid cytotoxicity on their oxidation potential is not strongly expressed, because the coefficients $\Delta \log \mathrm{cL}_{50} / \Delta \mathrm{E}_{7}\left(\mathrm{Q}^{-}-/\right.$ $\left.\mathrm{QH}_{2}\right)_{\text {(calc.) }}$ in Eqns. 2-4, 1.8-2.2 $\mathrm{V}^{-1}$, are lower than those describing the cytotoxicity of polyhydroxybenzenes in the same cell lines, 5.1-6.9 $\mathrm{V}^{-1}$ (Nemeikaitè-Čènienè et al., 2005; Grellier et al., 2008). The latter coefficients closely match the order of reactivity of polyphenols towards single-electron oxidants, $\Delta \log k / \Delta E_{7}\left(\mathrm{Q}^{-}-/ \mathrm{QH}_{2}\right)=\sim-8.5$ $\mathrm{V}^{-1}$ (Rich \& Bendall, 1980; Rich, 1982). Thus, apart from the ease of formation of prooxidant oxidation products or ROS, the cytotoxicity of flavonoids may be affected by other factors. A possible explanation is the interconversion of flavonoids under the action of cytochromes P-450 and COMT (Duarte Silva et al., 1997; Nielsen et al., 1998; Lautala et al., 2002; Lee et al., 2005), which may attenuate the expected dependence of cytotoxicity of flavonoids on their $E_{7}\left(\mathrm{Q}^{-}-/ \mathrm{QH}_{2}\right)$. Typically, O-methylation of catechols decreases their cytotoxicity, evidently due to an increase in their $E_{7}\left(Q^{-}-/ \mathrm{QH}_{2}\right)$, whereas their hydroxylation increases the autooxidation rate and cytotoxicity (Moridani et al., 2002a; 2002b). Although myricetin is not a substrate for cytochromes P-450 (Nielsen et al., 1998), and galangin does not possess hydroxy groups in B-ring, the data of Fig. 3A, B show that their cytotoxicity is modulated by inhibitors of cytochromes P-450 and COMT to a similar extent. Thus, O-methylation of myricetin by COMT (Lee et al., 2005) may be followed by the subsequent oxidative demethylation of the reaction products by cytochromes P-450. In turn, cytochromes P-450 may convert galangin into kaempferol, and, subsequently, into quercetin (Fig. 1) (Duarte Silva et al., 1997), which may be followed by $O$-methylation of quercetin by COMT (Lee et al., 2005). This is in line with the sufficiently close $\mathrm{cL}_{50}$ values for galangin, kaempferol, and quercetin in FLK cells (Table 2). Hesperetin and naringenin (Fig. 1) may also undergo the cytochrome P-450-catalyzed conversion into eriodictyol (Hodek et al., 2002), which may be also partly responsible for the similar cytotoxicity of the above flavanones (Table 2). Because flavonoids are $\mathrm{O}$-methylated much faster than catechols (Lautala et al., 2002), the action of COMT may decrease their cytotoxicity more efficiently. This may explain a less pronounced role of redox potential in the cytotoxicity of flavonoids as compared to that of polyhydroxybenzenes (Nemeikaité-Čenienè et al., 2005; Grellier et al., 2008).

\section{CONCLUSIONS}

Our studies have shown that the reactivity of flavonoids and related polyphenolic antioxidants with model single-electron oxidants may be a useful tool to characterize their $E_{7}\left(Q^{*}-/ \mathrm{QH}_{2}\right)$. Subsequently, this parameter may be used in the prediction of the cytotoxicity of flavonoids to the mammalian cell, which seems to be caused mainly by their prooxidant action. Another important factor to be considered is the reactions of flavonoids with cytochromes P-450 and COMT, which may significantly attenuate the dependence of the cytotoxicity of flavonoids on their $E_{7}\left(Q^{\circ}-/ \mathrm{QH}_{2}\right)$.

\section{Acknowledgements}

We are grateful to Prof. Saulius Klimašauskas (Institute of Biotechnology, Vilnius) for the access to the stopped-flow facility, and to Dr. Žilvinas Anusevičius (Institute of Biochemistry, Vilnius) for the assistance in the data analysis.

The support of the Scientific Council of Lithuania (The Project of the Global Grant Measure No. VP1-3.1SMM-07-K01-103) is gratefully acknowledged.

\section{REFERENCES}

Awad HM, Boersma MG, Boeren S, Van der Woude H, Van Zanden J, van Bladeren PJ, Vervoort J, Rietjens IMCM (2002) Identification of $o$-quinone/quinone methide metabolites of quercetin in a cellular in vitro system. FEBS Lett 520: 30-34.

Bandele OJ, Clawson SJ, Osheroff N (2008) Dietary polyphenols as topoisomerase II DNA-poisons: B ring and C ring substituents determine the mechanism of enzyme-mediated cleavage enhancement. Chem Res Toxicol 21: 1253-1260.

Boersma MG, Vervoort J, Szymusiak H, K. Lemanska K, Tyrakowska B, Ċenas N, Segura-Aguilar J, Rietjens IMCM (2000) Regioselectiv- 
ity and reversibility of the glutathione conjugation of quercetin quinone methide. Chem Res Toxicol 13: 185-191.

Bolton JL, Trush MA, Penning TM, Dryhurst G, Monks TJ (2000) Role of quinones in Toxicology. Chem Res Toxicol 13: 135-160.

Čenas N, Nemeikaite-Č̉nienè A, Šarlauskas J, Anusevičius Ž, Nivinskas H, Misevičiené L, Maroziené A (2009) Mechanisms of the mammalian cell cytotoxicity of explosives. In Ecotoxicology of explosives. Sunahara GI, Lotufo G, Kuperman RG, Hawari J, eds, pp 211-226. CRC Press, Boca Raton, London, New York.

Connors KA (1990) Chemical kinetics: the study of reaction rates in solution. VCH Publishers Inc., New York, Weinheim, Cambridge, 1990.

Duarte Silva I, Rodrigues AS, Gaspar J, Laires A, Rueff J (1997) Metabolism of galangin by rat cytochromes P450: relevance to the genotoxicity of galangin. Mutat Res 393: 247-257.

Galati G, Chan T, Wu B, O'Brien PJ (1999) Glutathione-dependent generation of reactive oxygen species by the peroxidase-catalyzed redox cycling of flavonoids. Chem Res Toxicol 12: 521-525.

Galati G, Sabzevari O, Wilson JX, O‘Brien PJ (2002) Prooxidant activity and cellular effects of the phenoxyl radicals of dietary flavonoids and other polyphenolics. Toxicology 177: 91-104.

Gamet-Payrastre LS, Manenti S, Gratacap M-P, Tulliez J, Chap H, Payrastre B (1999) Flavonoids and the inhibition of PKC and PI 3-kinase. Gen Pharmacol 32: 279-286.

Grellier P, Nemeikaite-Čeniené A, Šarlauskas J, Čènas N (2008) Role of single-electron oxidation potential and lipophilicity in the antiplasmodial in vitro activity of polyphenols: comparison to mammalian cells. $Z$ Naturforsch. 63c: 445-450.

Hodek P, Trefil P, Stiborova M (2002) Flavonoids - potent and versatile biologically active compounds interactiong with cytochromes P450. Chem-Biol Interact 139: 1-21.

Hou D-X, Kumamoto T (2010) Flavonoids as protein kinase inhibitors for cancer chemoprevention: direct binding and molecular modeling. Antioxid Redox Signal 13: 691-719.

Hynes MJ, Coinceanainn MO (2002) Investigation of the release of iron from ferritin by naturally occurring antioxidants. I Inorg Biochem 90: 18-21.

Inayat-Hussain SH, Winski SL, Ross D (2001) Different involvement of caspases in hydroquinone-induced apoptosis in human leukemic HL-60 and Jurkat cells. Toxicol Appl Pharmacol 175: 95-103.

Jorgensen LV, Skibstedt LH (1998) Flavonoid deactivation of ferrylmyoglobin in relation to ease of oxidation as determined by cyclic voltammetry. Free Rad Res 28: 335-351.

Jovanovic SV, Steenken S, Simic MG, Hara Y (1998) Antioxidant properties of flavonoids: reduction potentials and electron transfer reactions of flavonoid radicals. In: Flavonoids in bealth and disease. Rice-Evans CA, Packer L, eds, pp 137-161. Marcel Dekker Inc, New York, Basel, Hong Kong.

Lautala P, Ulmanen I, Taskinen J (2002) Molecular mechanisms controlling the rate and specificity of catechol-O-methylation by human soluble catechol-O-methyltransferase. Mol Pharmacol 59: 393-402.

Lee WJ, Shim J-Y, Zhu BT (2005) Mechanisms for the inhibition of DNA methyltransferases by thea catechins and bioflavonoids. Mol Pharmacol 68: 1018-1030.

Lee MH, Dan DW, Hyon SH, Park JC (2011) Apoptosis of human fibrosarcoma HT-1080 cells by epigallocatechin-3-O-gallate via induction of p53 and caspases as well as suppression of $\mathrm{Bcl}-2$ and phosphorylated nuclear factor- $x \mathrm{~B}$. Apoptosis 16: 75-85.

Lin WZ, Navaratnam S, Yao SD, Lin NY (1998) Antioxidative properties of hydroxycinnamic acid derivatives and a phenylpropanoid glycoside. A pulse radiolysis study. Radiat Phys Chem 53: 425-430.

Lu J, Papp LV, Rodriguez-Neto S, Zhivotovsky B, Holmgren A (2006) Inhibition of mammalian thioredoxin reductase by some flavonoids: implications for myricetin and quercetin anticancer activity. Cancer Res 66: 4410-4417.

Marcus RA, Sutin N (1985) Electron transfers in chemistry and biology. Biochim Biophys Acta 811: 265-322.

Metodiewa D, Jaiswal AK, Čènas N, Dičkancaité E, Segura-Aguilar J (1999) Quercetin may act as a cytotoxic prooxidant after its metabolic activation to semiquinone and quinoidal product. Free Rad Biol Med 26: 107-116.

Miyoshi N, Naniwa K, Yamada T, Osawa T, Nakamura Y (2007) Dietary flavonoid apigenin is a potential inducer of intracellular oxidative stress: the role in the interruptive apoptotic signal. Arch Biochem Biophys 466: 274-282.

Moini H, Arroyo A, Vaya J, Packer L (1999) Bioflavonoid effects on the mitochondrial respiratory electron transport chain and cytochrome $c$ redox state. Redox Rep 4: 35-41.
Moridani MY, Cheon SS, Khan S, O'Brien PJ (2002a) Metabolic activation of 4-hydroxyanisole by isolated rat hepatocytes. Drug Metab Dispos 30: 1063-1069.

Moridani MY, Scobie H, O`Brien PJ (2002b) Metabolism of caffeic acid by isolated rat hepatocytes and subcellular fractions. Toxicol Lett 133: 141-151.

Moridani MY, Siraki A, O‘Brien PJ (2003) Quantitative structure toxicity relationships for phenols in isolated rat hepatocytes. Chem-Biol Interact 145: 213-223.

Morin D, Barthelemy S, Zini R, Labidalle S, Tillement JP (2001) Curcumin induces the mitochondrial permeability transition pore by membrane protein thiol oxidation. FEBS Lett 495: 131-136.

Morita K, Arimochi H, Ohnishi Y (2003) In vitro cytotoxicity of 4-methylcatechol in murine tumor cells: induction of apoptotic cell death by extracellular pro-oxidant action. I Pharmacol Exp Therap 306: $317-323$.

Mouria M, Goukovskaya AS, Young Y, Buechler P, Hines OJ, Reber HA, Pandol SJ (2002) Food-derived polyphenols inhibit pancreatic cancer growth through mitochondrial cytochrome $c$ release and apoptosis. Int J Cancer 98: 761-769.

Nemeikaitė-Č̉niené A, Imbrasaitė A, Sergediené E, Čènas N (2005) Quantitative structure-activity relationships in prooxidant cytotoxicity of polyphenols: role of potential of phenoxyl radical/phenol redox couple. Arch Biochem Biophys 441: 182-190.

Nielsen SE, Breiholdt V, Justesen U, Cornett C, Dragsted LO (1998) In vitro biotransformation of flavonoids by rat liver microsomes. Xenobiotica 28: 389-401.

O'Brien PJ (1991) Molecular mechanisms of quinone cytotoxicity. Chem-Biol Interact 80: 1-41.

Oikawa S, Furukawa A, Asada H, Hirakawa K, Kawanishi S (2003) Catechins induce oxidative damage to cellular and isolated DNA through the generation of reactive oxygen species. Free Rad Res 37: 881-8980.

Öllinger K, Brunmark A (1991) Effect of hydroxy substituent position on 1,4-naphthoquinone toxicity to rat hepatocytes. J Biol Chem 266: 21496-21503.

Rich PR (1982) Electron and proton transfers in chemical and biochemical quinone systems. Faraday Discuss Chem Soc 74: 349-364.

Rich PR, Bendall DS (1980) The kinetics and thermodynamics of the reduction of cytochrome $c$ by substituted $p$-benzoquinols in solution. Biochim Biophys Acta 592: 506-518.

Robaszkiewicz A, Balcerczyk A, Bartosz G (2007) Antioxidative and prooxidative effects of quercetin on A549 cells. Cell Biol International 31: 1245-1250.

Salvi M, Brunati AM, Clari G, Toninello A (2002) Interaction of genistein with the mitochondrial electron transport chain results in the opening of the membrane transition pore. Biochim Biophys Acta 1556: $187-156$.

Sergediené E, Jönsson K, Szymusiak H, Tyrakowska B, Rietjens IM, Cénas N (1999) Prooxidant toxicity of polyphenolic antioxidants to HL-60 cells: description of quantitative structure-activity relationships. FEBS Lett 462: 392-396.

Sharma V, Joseph C, Ghosh S, Agarwal A, Mishra MK, Sen E (2007) Kaempferol induces apoptosis in glioblastoma cells through oxidative stress. Mol Cancer Ther 6: 2544-2553.

Shen SC, Ko CH, Tseng SW, Tsai SH, Chen YC (2004) Structurally related antitumor effects of flavanones in vitro and in vivo: involvement of caspase 3 activation, p21 gene expression, and reactive oxygen species production. Toxicol Appl Pharmacol 197: 84-95.

Terland O, Almås B, Flatmark T, Andersson KK, Sorlie M (2006) One-electron oxidation of catecholamines generates free radicals with an in vitro toxicity correlating with their lifetime. Free Rad Biol Med 41: 1266-1271.

Uchimiya M, Gorb L, Isayev O, Qasim MM, Leszczynski J (2010) One-electron standard reduction potentials of nitroaromatic and cyclic nitramine explosives. Environ Pollut 158: 3048-3053.

Wardman P (1989) Reduction potentials of one-electron couples involving free radicals in aqueous solutions. J Phys Chem Ref Data 18: 1637-1755.

Webb MR, Ebeler SE (2004) Comparative analysis of topoisomerase IB inhibition and DNA intercalation by flavonoids and similar compounds: structural determinantes of activity. Biochem J 384: 527-541.

Yoshino M, Murakami K (1998) Interaction of iron with polyphenolic compounds: application to antioxidant characterization. Anal Biochem 257: $40-44$. 